\title{
HALINA ŚWIĘCZKOWSKA
}

(Białystok)

\section{O PEWNYCH ASPEKTACH LEIBNIZJAŃSKIEJ FILOZOFII UMYSEU}

\section{Wprowadzenie}

Na okładce wydanej w polskim tłumaczeniu głośnej książki amerykańskiego matematyka Keitha Devlina Żegnaj, Kartezjuszu. Rozstanie z logika w poszukiwaniu nowej kosmologii umystu ${ }^{1}$ czytamy, że refleksja nad językiem i ludzkim myśleniem odegrała ogromną rolę w dziejach filozofii i nauki. Dziś - w dobie badań nad sztuczną inteligencją i rozwoju technik informacyjnych - szczególnej wagi nabrały prace psychologów i filozofów języka, socjologów i lingwistów. Odpowiedzi na pytania: czym jest język, czym jest ludzki umysł, w jaki sposób myślimy, mają kluczowe znaczenie dla rozwiązania podstawowych problemów informatyki. Narodziny nowej dyscypliny, kognitywistyki, która zajmuje się strukturą umysłu, myśleniem i świadomością, stały się wyzwaniem dla tradycji filozoficznej, między innymi kartezjanizmu, a jednocześnie istotnym czynnikiem rozwoju technik komputerowych i komunikacyjnych. Devlin rozlicza się z tradycją, której kształt definiuje, jego zdaniem, figura Kartezjusza, jego filozofia, a przede wszystkim jego metodologia. Można oczywiście traktować Kartezjusza jako symbol całego dziedzictwa racjonalizmu, wydaje się jednak, że mimo jego ogromnego wpływu na filozofię nowożytną, to nie Kartezjusz, a Leibniz powinien stać się głównym bohaterem pożegnania, któremu tak naprawdę nie ma końca. Niniejszy tekst nie jest jednak próbą polemiki z poglądami Devlina, ale raczej częściowym ich uzupełnieniem. Przedstawiam tu wybrane problemy Leibnizjańskiej

\footnotetext{
1 K. Devlin, Żegnaj Kartezjuszu. Rozstanie z logika w poszukiwaniu nowej kosmologii umystu,
} tłum. B. Stanosz, Prószyński i S-ka, Warszawa 1999. 
teorii umysłu, budowanej przede wszystkim na językowym fundamencie, które jak się wydaje, pozwalają dostrzec w Leibnizu rzeczywistego prekursora współczesnej kognitywistyki.

\section{Błąd jako skutek ograniczeń umysłu}

W Rozprawie metafizycznej Leibniz objaśniając naturę substancji, zwraca uwagę, że wszystkie jej postrzeżenia są zawsze prawdziwe, ,a tylko sądy, które pochodzą od nas, w błąd wprowadzają" ${ }^{2}$. Należy pamiętać, że według Leibniza każda indywidualna substancja „przedstawia cały wszechświat” 3 i jest żywym, „czyli obdarzonym wewnętrzną czynnością zwierciadłem, przedstawiającym wszechświat ze swego punktu widzenia i poddanym tym samym co on prawom" 4 . Ponadto każdy ogląd wszechświata realizowany przez wszelką substancje pozostaje w doskonałej zgodności z perspektywą posiadaną przez Boga. Prawdziwość zaś „widoku boskiego" stanowi, zdaniem Leibniza, gwarancje prawdziwości postrzeżeń stworzonych przez Boga substancji ${ }^{5}$. Ta argumentacja nie budzi zastrzeżeń, gdy bierzemy pod uwage same tylko postrzeżenia. Można tu bowiem przyjąć za Hobbesem, że „natura sama w sobie nie może się mylić” ${ }^{6}$, a zatem, jeśli godzimy się na istnienie duszy u dżdżownicy czy pszczoły, to uznajemy także, że dusze tych zwierząt postrzegają - na mocy przysługującego im wewnętrznego systemu reprezentacji - cały wszechświat. Mówiąc o postrzeżeniach, mamy do tej pory na uwadze jedynie te, które Leibniz nazywa nieuświadomionymi. Powstaje tu jednak pytanie: czy, jeśli prawdziwe są wszelkie postrzeżenia mające taki właśnie status, to prawdziwe są także te, które stanowią ich modyfikację - mianowicie postrzeżenia uświadomione, czyli apercepcje ${ }^{7}$.

2 G.W. Leibniz, Rozprawa metafizyczna, w: tenże, Wyznanie wiary filozofa, Rozprawa metafizyczna, Monadologia, Zasady natury i laski oraz inne pisma filozoficzne, tłum. S. Cichowicz, J. Domański, H. Rzeczkowski, H. Moese, opracował i wstępem poprzedził S. Cichowicz, PWN, Warszawa 1969, s. 114.

3 G.W. Leibniz, Monadologia, § 62, w: tenże, Wyznanie wiary filozofa..., wyd. cyt., s. 310.

4 G.W. Leibniz, Zasady natury $i$ taski oparte na rozumie, $\S 3$, w: tenże, Wyznanie wiary filozofa..., wyd. cyt, s. 284 .

5 G.W. Leibniz, Rozprawa metafizyczna, w: tenże, Wyznanie wiary filozofa..., wyd. cyt, s. 113.

6 The English Works of Thomas Hobbes, red. W. Moleswortha, J. Bohn, London 1839-1845, vol. III, s. 25 .

7 Leibniz wyraźnie odróżnia atrybuty i modyfikacje. „Zdolności spostrzegania i działania, rozciągłość, stałość są atrybutami i orzeczeniami wiecznymi i zasadniczymi; natomiast myślenie, gwałtowność, kształty, ruchy są modyfikacjami tych atrybutów"; G.W. Leibniz, Nowe rozważania dotyczace rozumu ludzkiego, tłum. I. Dąmbska, PWN, Warszawa 1955, t. I, Przedmowa, s. 29. Wynika stąd, że apercepcja jako zdolność do uświadamiania sobie treści postrzeżeń, czyli $\mathrm{w}$ istocie zdolność do myślenia, jest modyfikacją spostrzegania (percepcji). Por G.W. Leibniz, Zasady natury i taski..., § 4, w: tenże, Wyznanie wiary filozofa..., wyd. cyt., s. 285. 
Apercepcja jest dla Leibniza świadomością, czyli „refleksyjnym poznaniem wewnętrznego stanu monady przedstawiającym rzeczy zewnętrzne" ${ }^{8}$. Należy wyraźnie podkreślić, że apercepcja przysługuje wyłącznie umysłom, które oprócz tego, „że są żywymi zwierciadłami czy tė̇ obrazami świata stworzeń", są także „obrazami (...) samego Twórcy natury, zdolnymi do poznania systemu wszechświata" 9. Jeśli weźmiemy pod uwagę, że każdy umysł wyposażony jest w wewnętrzny idealny system reprezentacji, odpowiadający systemowi wszechświata, wynika stąd, że także każde postrzeżenie podniesione do poziomu apercepcji jest postrzeżeniem prawdziwym. Jedyna różnica między postrzeganiem (percepcją) a apercepcją, polega zatem na bezpośrednim wglądzie w świat idei, któremu towarzyszy refleksja. Można powiedzieć po prostu, że nie tylko postrzegamy, ale wiemy, co postrzegamy. Zdolność do apercepcji jest u Leibniza w istocie zdolnością do samego myślenia, które prowadzi bezpośrednio do idei rzeczy ${ }^{10}$.

Takie ujęcie świadomości wyklucza jednak jakiekolwiek inne stany poznawcze umysłu, które nie pozostają w żadnym związku z porządkiem idealnym. Jeśli istotę każdej substancji stanowi dążność sterująca postrzeżeniami, które są zawsze prawdziwe, jak w takim razie uzasadnić istnienie w umyśle pojęć i sądów, które nie mają oparcia w ideach, a które, jak pisze Leibniz, „pochodzą od nas i w błąd nas wprowadzają"?

Pytanie to dotyczy istoty leibnizjańskiej metafizyki, gdyż przypisanie substancji błędnych sądów może implikować błąd w boskiej perspektywie świata. Inny aspekt tego problemu dotyczy samej możliwości błędu w kontekście doskonałej harmonii, która raz na zawsze uporządkowała wszystko w rzeczach z odpowiedniością wzajemną ${ }^{11}$. Odpowiedzi na te i inne pytania - jak się wydaje - związane są bezpośrednio z metafizycznym statusem owych błędnych myśli ${ }^{12}$.

8 G.W. Leibniz, Zasady natury i taski.., § 4, w: tenże, Wyznanie wiary filozofa..., wyd. cyt., s. 285 .

9 G.W. Leibniz, Monadologia, § 83, w: tenże, Wyznanie wiary filozofa..., wyd. cyt., s. 313.

10 Zob. G.W. Leibniz, Quid sit idea, w: tenże, Die philosophischen Schriften von G.W. Leibniz, red. C.I. Gerhardta, Halle 1849-1863 (repr. Hildesheim 1960; dalej cytowane jako GP), t. VII, s. 263.

11 Por. G.W. Leibniz, Zasady natury i taski..., § 13, w: tenże, Wyznanie wiary filozofa..., wyd. cyt., s. 291.

12 Problem ten rozważa Noa Zauderer-Naaman w artykule: The Challenge Posed by the Problem of Error for Leibniz's Metaphysic, w: Leibniz und Europa, VI Internationaler Leibniz-Kongreß Vortrage, I Teil, Hannover 1994. Zob. także Introduction, w: G.W. Leibniz, Philosophical Papers and Letters, red. L. E. Loemkera, D. Reidel Publishing Company, Dordrecht 1965, s. 44 (oznaczane dalej jako L). 


\section{Myślenie a reprezentacja}

Kiedy Leibniz pisze, że każde działanie umysłu jest myślą ${ }^{13}$, nie znaczy to, że każda myśl wyraża jakąś ideę. Dotyczy to wyłącznie tych myśli, które prowadzą do idei i jako takie są skutkiem postrzeżeń. Ale dzięki zdolności do poznania umysł może także w sposób aktywny tworzyć różne myśli. Wprawdzie „Idee wszelkiej rzeczy mamy w swej duszy dzięki ustawicznemu działaniu Boga" 14, ale wyposażając umysły w idealny system reprezentacji, Bóg udzielił nam tylko pewnej zdolności do jego rozpoznania, pozwalając myśleć także o tym, czego idei nie posiadamy. Nie znaczy to jednak, że działamy w sposób wolny. Ściśle mówiąc, nie mamy nigdy doskonałej wolności. Mimo to cieszymy się jednak pewnym jej stopniem, którego nie mają zwierzęta, mamy bowiem zdolność „rozumowania oraz wyboru podług tego, co się nam wydaje" ${ }^{15}$. Ten element wolności może polegać na tym, że Bóg nie uczestniczy przy tworzeniu przez nas każdej myśli. „To więc, że mamy w sobie ideę rzeczy, tylko na tym polega, że stwórca zarówno rzeczy, jak i umysłu, wyrył w umyśle tę zdolność myślenia, która mu pozwala wyprowadzić coś ściśle odpowiadającego temu, co wynika z samych rzeczy" 16 . Prowadzi to zatem do wniosku, że idee nie są bezpośrednio dostępne naszej świadomości i tylko dzięki zdolności do myślenia, dzięki procesom analizy treści naszych myśli, jesteśmy w stanie nadać myślom reprezentatywny charakter ${ }^{17}$.

Żaden sąd fałszywy nie jest przedmiotem percepcji, to znaczy nie istnieje odpowiadający mu w umyśle układ idei. Wydaje się zatem, że stan poznawczy umysłu, który dopuszcza taki sąd, nie może być postrzegany przez jakąkolwiek inną substancję prostą, jest bowiem, jak pisze Leibniz, tylko „pojawem” lub „nicością" ${ }^{18}$, obecną w naszej świadomości, w tym jej obszarze, który nie jest izomorficzny z apercepcją. Można na tej podstawie przypuszczać, że Leibniz zakłada

13 „Omnis (...) actio animi est cogitatio...”; G.W. Leibniz, Nova Methodus..., w: G.W. Leibniz, Sämtliche Schriften und Briefe, herausgegeben von der Preussischen (ject Deutschen) Akademie der Wissenschaften zu Berlin, 6 Reihen, Darmstadt 1923, Leipzig 1983, Berlin 1950, VI, i, 284 (dalej cytowane jako AA, tom, część, strona).

14 G.W. Leibniz, Rozprawa metafizyczna, w: tenże, Wyznanie wiary filozofa..., wyd. cyt., s. 132.

15 G.W. Leibniz, O wolności ludzkiej $i$ o źródle zła, w: tenże, Wyznanie wiary filozofa..., wyd. cyt., s. 150 .

16 Tenże, Quid sit idea, GP VII, 263; Czym by miala być idea, w: M. Gordon, Leibniz, Wiedza Powszechna, Warszawa 1973, s. 222.

17 Pamiętajmy, że dla Leibniza idee mają charakter dyspozycyjny. Zob. tenże, Nowe rozważania..., wyd. cyt., t. I, s. 11.

18 Por. G.W. Leibniz, O wolności ludzkiej i o źródle zla, w: tenże, Wyznanie wiary filozofa..., wyd. cyt., s. 153. 
dwa znaczenia słowa „świadomość” - węższe, które nazywa apercepcją, i szersze, obejmujące wszelkie stany psychiczne i towarzyszące im stany intelektualne. Ta „wolna”, a jednocześnie niedoskonała ${ }^{19}$ część świadomości, stanowi źródło i przyczynę błędnych myśli i pustych pojęć. W Dialogu o powiązaniu stów i rzeczy oraz o naturze prawdy odpowiedź na pytanie: Czy rzecz jakaś jest fałszywa?, brzmi: „Nie rzecz (...), lecz myśl lub zdanie o rzeczy” 20.

Jeśli przyjmiemy, że system idei odzwierciedla system wszechświata na wszystkich poziomach jego złożoności, począwszy od zjawisk dobrze ugruntowanych aż po elementarne składniki podziału, to system ten, jeśli weźmiemy pod uwage nieskończoność podziału materii (którą utożsamiać należy ze zjawiskami dobrze ugruntowanymi), jest dla umysłu do końca w całości niepoznawalny. Wynika to z ograniczeń samego umysłu. Ograniczenie bowiem stanowi dla Leibniza istotę umysłu, co prowadzi do wniosku, że „nie może on znać wszystkiego i że może się łudzić i popełniać inne błędy" ${ }^{21}$. Istoty rzeczy są wieczne, choć rzeczy wieczne nie są. Źródłem istot rzeczy takich, jakimi są, jest Intelekt Boski. A zatem niedoskonałość umysłów nie zależy od woli Bożej, podobnie jak od jego woli nie zależą własności liczb. „Zawsze było prawdziwe, że trzy razy trzy daje dziewięć i będzie je zawsze dawać" 22. Argumentacja Leibniza dotycząca ograniczonego charakteru ludzkiego umysłu i innych stworzeń budzi wiele kontrowersji. Sugeruje jednak, że ostateczne źródło błędu (a szerzej wszelkiego zła) jest metafizyczne 23 .

Nie jesteśmy zatem wolni, gdyż z istoty swojej skazani jesteśmy na błądzenie - „Bóg bowiem nie mógłby dać stworzeniu wszystkiego, nie czyniąc go bogiem, dlatego muszą z konieczności istnieć różne stopnie doskonałości rzeczy, jak również wszelkiego rodzaju ograniczenia" ${ }^{24}$. Leibniz dodaje jednak, że umysł ludzki, oprócz swej reprezentatywnej natury, inaczej niż inne substancje, zdolny

19 Świadomość jest niedoskonała, ponieważ jest ograniczona, albo niedoskonała na mocy zasady negacji lub nicości, którą zawiera. Por. G. W. Leibniz, O wolności ludzkiej i o źródle zła, w: tenże, Wyznanie wiary filozofa..., wyd. cyt., s. 153.

20 G.W. Leibniz, Dialog..., w: tenże, Wyznanie wiary filozofa..., wyd. cyt., s. 77.

21 G.W. Leibniz, Teodycea, § 23, GP IV, 115. Problem pogodzenia infinitystycznej koncepcji rzeczywistości z finitystycznym ujęciem umysłu omawia W. Marciszewski w artykule: Why Leibniz should not have believed in "filum cogitationis", w: Leibniz und Europa, VI Internationaler Leibniz-Kongreß, wyd. cyt. Zob. też W. Marciszewski, Leibniz's Idea of Automated Reasoning Compared with Modern Al oraz A. Drozdek, Leibniz: Struggles with Infinity, w: On Leibniz Legacy in the 350 Anniversary of His Birth, series: "Studies in Logic, Grammar and Rhetoric", Białystok 1997.

22 G.W. Leibniz, O wolności ludzkiej $i$ o źródle zła, w: tenże, Wyznanie wiary filozofa..., wyd. cyt., s. 154 .

23 Por. F. Copleston, Historia filozofi, tłum. J. Marzęcki, Instytut Wydawniczy PAX, Warszawa 1995 , t. IV, s. 325.

24 G.W. Leibniz, Teodycea, § 31, GP IV, 121. 
jest do poznania systemu wszechświata i do częściowego jego naśladowania za pomocą prób architektonicznych; „każdy duch jest niczym małe bóstwo w swym zakresie" 25. Wynika stąd, że człowiekowi przysługuje coś więcej, niż wynika to z reprezentatywnego charakteru substancji. Człowiek ma prawo do twórczego naśladownictwa.

Zdolność do poznania jest wpisana w naturę umysłu, jest dążnością, która ujawnia się jako skutek w akcie apercepcji. Ograniczenia umysłu sprawiają jednak, że musi on posiłkować się w procesie myślenia pewnymi narzędziami, które naśladują dany mu wewnętrzny, idealny system reprezentacji. Gdyby nie te ograniczenia, umysł poznawałby istotę rzeczy bezpośrednio, dzięki oglądowi ich idei. Poznanie takie nazywa Leibniz intuicyjnym. „A choć nie wiem - jak pisze - czy jego przykład doskonały znaleźć można pośród tego, co dane człowiekowi, jednakże bardzo doń się zbliża wiedza o liczbach" 26.

Leibniz przypisując fałszywość sądom i zdaniom, ma na uwadze tę część świadomości, której towarzyszą pewne stany językowe, jakaś symbolika, wtórna w pewnym sensie wobec działań samego umysłu. Można przypuszczać więc, że język naturalny, a także jakikolwiek system znaków, jest niejako konsekwencją ograniczoności umysłu. Powstał, ponieważ człowiek z istoty swojej nie jest zdolny do pełnego poznania intuicyjnego, ale też dlatego, że człowiek posiada zdolność do poznania w ogóle i zdolność do częściowego naśladowania systemu Wszechświata. Język posiada więc jakby dwa oblicza - jest systemem deszyfrującym wewnętrzny porządek reprezentacji, ale będąc dziełem człowieka, dopuszcza błąd i może prowadzić w obszar nicości.

\section{Świat przyrody i twórczość człowieka}

Jak zauważyliśmy wcześniej, Leibniz, nadając światu zewnętrznemu status zjawiskowy, widzi w nim dzieło Boskiego Architekta, przeciwstawiając go skutkom twórczej aktywności człowieka. „Albowiem machina stworzona sztuką człowieka nie jest machiną w każdej swojej części. (...) Wszelako machiny natury, czyli żywe ciała, są machinami w swych najdrobniejszych częściach aż po nieskończoność" ${ }^{27}$. Choć świat przyrody ma u Leibniza charakter zjawiskowy, jest to

25 G.W. Leibniz, Monadologia, § 83, w: tenże, Wyznanie wiary filozofa..., wyd. cyt., s. 315.

26 G.W. Leibniz, Meditationes de cognitione, veritate et ideis, GP IV, 423; tenże, Rozmyślania nad poznaniem, prawda oraz ideami, w: M. Gordon, Leibniz, wyd. cyt. s. 238.

27 G.W. Leibniz, Monadologia, § 64, w: tenże, Wyznanie wiary filozofa..., wyd. cyt., s. 311. 
jednak świat, w którym każde zjawisko jest dobrze ugruntowane ${ }^{28}$ : „(...) złożoną substancję cielesną przypisuję jedynie istotom żywym, czyli samym tylko maszynom organicznym przyrody. Pozostałe zaś uważam za czcze agregaty substancji; agregat zaś stanowi wyłącznie jedność przygodną" ${ }^{29}$. Owe złożone substancje cielesne składają się wprawdzie z nieskończonej ilości substancji prostych będących w ciągłym ruchu, ale swoje „dobre ugruntowanie” zawdzięczają działaniu zasady pojedynczości ${ }^{30}$, zgodnie z którą każde ciało organiczne (substancja cielesna) posiada pewną monadę jednostkowiącą to ciało, stanowiącą o jego odrębności. Leibniz pisze wyraźnie, że „Chociaż (...) każda monada stworzona przedstawia cały wszechświat, wyraźniej przedstawia jedynie ciało, które w szczególności jest jej przydzielone". Ciało zaś stanowi z ową monadą (duszą) to, co nazwać można żyjątkiem lub zwierzęciem. „Tak więc każde organiczne ciało żyjątka staje się czymś w rodzaju machiny Boskiej, czyli automatu naturalnego, przewyższającego nieskończenie automaty sztuczne" ${ }^{31}$. Leibniz utrzymuje, że wytworom człowieka brakuje substancjalnej jedności. Brak jednostkowiącej substancji - entelechii lub duszy - decyduje zatem o wyłącznie zjawiskowym charakterze tych obiektów; są one jedynie nagromadzeniem substancji, „zwykłym agregatem, jak w przypadku stosu kamieni (...) zjednoczeniem przygodnym (per accidens)" 32 .

Jeśli poprawnie rozumiemy argumentację Leibniza, to świat natury jawiący się nam w doświadczeniu, odwzorowany jest w postaci idealnego systemu reprezentacji, w którym istnieją także odpowiednie pojęcia czy idee gwarantujące substancjalną jedność zjawiskom dobrze ugruntowanym. Można również zakładać, że sam wszechświat posiada substancjalną jedność, która wyrażona jest pewną ideą. Jeśli istnieje jedna rzeczywistość, to istnieje także jeden idealny, odpowiadający jej system reprezentacji, który jest z tą rzeczywistością izomorficzny. Ten właśnie system jest przedmiotem poznania.

Leibniz czyni ze zdolności do poznania jedną z cech przysługujących wyłącznie umysłowi ludzkiemu. Drugą z nich stanowi właściwa również tylko człowiekowi zdolność do naśladowania systemu natury. Jeśli rezultaty twórczej działalności człowieka są czystymi zjawiskami, mającymi przypadkową jedność, to biorąc pod uwage zdanie Leibniza, że każdy umysł jest małym bóstwem, można zapytać, czy status wszystkich skutków aktywności ludzkiej jest rzeczywiście taki sam.

28 G.W. Leibniz, Uwagi na temat pierwiastków życia..., w: tenże, M. Gordon, Leibniz, wyd. cyt. s. 208.

29 G.W. Leibniz, List do Masona z 1716 r., w: M. Gordon, Leibniz, wyd. cyt., s. 220.

30 G.W. Leibniz, Zasady natury i laski, § 3, w: tenże, Wyznanie wiary filozofa..., wyd. cyt. s. 284.

31 G.W. Leibniz, Monadologia, § 64, w: tenże, Wyznanie wiary filozofa..., wyd. cyt., s. 311.

32 List do des Bossesa z 20 VIII 1712 r., w: M. Gordon, Leibniz, wyd. cyt. s. 212. 
Dzięki zdolności do poznania człowiek wnika pod powierzchnię surowych danych obserwacyjnych w poszukiwaniu ukrytego porządku. Istotą nauki bowiem jest odkrywanie struktur i regularności w przyrodzie poprzez wynajdywanie sposobów upraszczania danych. Człowiek nie zadowala się jednak samym poznaniem, dąży także do twórczego wykorzystania zdobytej wiedzy. Leibniz wierzył, że podstawowy porządek wszechświata da się ująć w postaci matematycznej ${ }^{33}$. Na marginesie rękopisu Dialogu... dopisał zdanie, które należy do najcelniejszych jego aforyzmów: „Gdy Bóg rachuje i snuje myśli, świat się staje” 34 . Pamiętamy, że dla Leibniza umysł ludzki ma naturę zbliżoną do umysłu Boskiego, różniąc się doskonałością czynności. Jeśli rachunek służy Bogu do stworzenia wszechświata, to jedynym pewnym narzędziem poznania rzeczywistości jest system izomorficzny z boskim rachunkiem, algorytmem, który wpisany jest w umysł jako wewnętrzny system reprezentacji. Ale człowiek nie ma bezpośredniego dostępu do tego systemu, idee mają bowiem charakter dyspozycyjny. Stany wglądu w idealny system reprezentacji, apercepcje, są rejestrowane i porządkowane przez umysł, który posiłkuje się w tym procesie jakimś stworzonym przez siebie kodem, „utrwalającym” niejako sposób rozpoznania rzeczy ${ }^{35}$. Jeśli ten kod odwzorowuje ów wewnętrzny system reprezentacji w jakimś jego fragmencie, to wydaje się, że można zakładać pewien stopień ugruntowania tego kodu, który przestaje już być przypadkowym zjawiskiem, gdyż znajduje odpowiednik w postaci idei reprezentującej jakiś fragment rzeczywistości. Leibniz twierdził zresztą, że tę samą rzeczywistość można prawdziwie wyrazić w różnych systemach znaków, byle tylko został zachowany izomorfizm relacji rzeczy i znaków. Może to zatem znaczyć, że dowolny system językowy spełniający ten warunek, spełnia również w jakiejś mierze kryterium „ugruntowania”.

Warto podkreślić, że inaczej niż Bacon, Hobbes, czy Kartezjusz, Leibniz rozważając istotę języka, opowiada się raczej za jej naturalistycznym ujęciem. Jego spojrzenie na język wyznacza w znacznej mierze tradycja platońska. Przypomnijmy, że problem związku między językiem a rzeczywistością, sprowadzony w filozofii greckiej do pytania, co stanowi wiarygodne źródło naszego poznania: nazwy rzeczy czy same rzeczy, Platon rozwiązuje następująco. Słowa są wprawdzie

33 Przekonanie, że w świecie fizycznym przejawia się ład i harmonia matematyczna zrodziło się już w starożytnej Grecji. Jego rozkwit nastąpił w Europie okresu Odrodzenia wraz z pracami Galileusza, Newtona, Kartezjusza i Leibniza. Galileusz głosił, że „Księga przyrody napisana jest językiem matematyki". Pogląd, że podstawowy porządek świata da się ujać w postaci matematycznej jest również osią współczesnej nauki. Zob. P. Davies, Plan Stwórcy, tłum. Marek Krośniak, Wydawnictwo ZNAK, Kraków 1996, s. 154 i n.

34 G.W. Leibniz, Dialog..., w: tenże, Wyznanie wiary filozofa..., wyd. cyt. s. 79.

35 Pamiętać wszak należy, że te stany wglądu mają charakter stopniowalny i prowadzą do różnego sposobu wyrażania rzeczy. Por. tenże, Rozmyślania nad poznaniem, prawda oraz ideami, w: M. Gordon, Leibniz, wyd. cyt., s. 236-240. 
nieodzownym narzędziem w procesie poznania, ponieważ istnieją pewne naturalne związki pomiędzy nimi a rzeczami, ale język sam w sobie jest zależny i pochodny od świata rzeczy. Rzeczy istnieją niezależnie od tego, czy posiadamy wiedzę o nich oraz czy odpowiada im jakaś nazwa. Umysł poznając świat wnika w naturę rzeczy istniejaccych autonomicznie, następnym działaniem jest dołączenie słowa. Istotny staje się tu zatem związek między wiedzą a językiem. Nazwy nie istnieją bowiem samodzielnie, zawsze pozostają w relacji do czegoś. Są narzędziem pozwalającym rozróżnić i porządkować podpadające pod nie przedmioty i jako takie są niezbędne w nauczaniu, zaś sama analiza nazw pomocna jest w rozpoznawaniu istoty rzeczy. Ale choć język jest warunkiem koniecznym wszelkiej wiedzy, nie jest jednak dla niej warunkiem wystarczającym. Język jest dla Platona tylko początkowym etapem procesu poznania. Na drodze dojścia do prawdy każdy poznawany przedmiot jawi się w poczwórny sposób. Wyraża się w nazwie, rysuje w obrazie, precyzuje w definicji, przedstawia w umysłowym ujęciu i wiedzy o przedmiocie. Ale te wszystkie ujawnienia są niedoskonałe. Choć są konieczne, nie wystarczają jednak do zdobycia i ukazania innym piątego, doskonałego poznania, ono bowiem nie daje się ująć w słowa ${ }^{36}$. Zwróćmy uwage na podobieństwo klasyfikacji stanów poznawczych przedstawione przez Leibniza w Rozmyślaniach nad poznaniem, prawda oraz ideami. Również język, przynajmniej u jego źródeł, zdaniem Leibniza, nie był skutkiem żadnej racjonalnej decyzji, ale wyznaczony został przez „jakieś racje już to naturalne, gdzie i przypadek ma swój udział, już to moralne, gdzie w grę wchodzi wybór" ${ }^{37}$. Te racje naturalne, siegające istoty rzeczy, decydowałyby o wspomnianym wyżej „ugruntowaniu” języka. Pamiętajmy, że dla Leibniza każdy skutek ma swoją przyczynę, zatem jeśli język jest skutkiem pewnych naturalnych racji, to jest wprawdzie wobec nich wtórny, ale też na podstawie analizy języka jesteśmy zdolni do ich poznania.

Leibniz dając człowiekowi prawo do twórczego naśladownictwa, niewątpliwie brał pod uwagę cywilizacyjny dorobek ludzkości. Sam zafascynowany technologią mechaniczną dał się poznać jako zdolny konstruktor i inżynier. Dziwi zatem jego radykalne rozróżnienie między naturą i kulturą, zwłaszcza że każdy wynalazek, każda nowa technologia jest konsekwencją wykorzystania odkrytych praw przyrody. Można zgodzić się z jego argumentem, że zegar ciężarkowy nie ma jedności substancjalnej (duszy), ale nie sposób zaprzeczyć, że u podstaw jego działania leżą prawa mechaniki, które określiły takie właśnie wykorzystanie materii. Pewną trudność interpretacyjną stanowią współczesne eksperymenty badawcze będące następstwem złamania kodu genetycznego. Można bowiem zapytać, czy sklono-

36 Zob. Platon, List VII, 341 c, 342, w: Platon, Listy, tłum. M. Maykowska, PWN, Warszawa 1987.

37 G.W. Leibniz, Nowe rozważania..., wyd. cyt., t. II, s. 14-12. 
wana owca ma duszę, czy też jest zwykłym nagromadzeniem substancji. Takich pytań jest wiele i wydaje się, że pewnym rozwiązaniem jest zastosowanie wobec świata kultury Leibnizjańskiej zasady ciągłości. Otóż wszędzie tam, gdzie wytwory człowieka są następstwem odkrytych przezeń praw, znajdują one swoje umocowanie w istniejącym idealnym systemie reprezentacji. Jeśli nawet nie mają wymaganej jedności substancjalnej, to ich istnienie w świecie fizycznym jest w pewnym tylko sensie zjawiskowe, gdyż dzięki odniesieniu do świata przyrody ocierają się o granicę zjawisk dobrze ugruntowanych.

\section{Człowiek jako zwierzę symboliczne}

Rozważając problem błędu Leibniz podkreśla, że to nie Bóg oszukuje, „lecz własny nasz sąd, gdy twierdzić coś będziemy bez dokładnego dowodu" 38 . W Liście do S. Fouchera pisze, że ,jedynie wtenczas człowiek pojmuje doskonale rzecz, o jaką chodzi, kiedy potrafi dowieść tego, co właśnie głosi” 39. Jest również zdania, że żaden sąd nie powinien być przyjęty bez dowodu, ani żadne słowo bez wyjaśnienia ${ }^{40}$. Oprócz tego wyraża przekonanie, że „wszelkie ludzkie rozumowanie dokonuje się poprzez jakieś znaki, czyli charaktery. Nie tylko bowiem same rzeczy, lecz także idee rzeczy ani nie mogą, ani nie powinny zawsze być wyraźnie przez umysł postrzegane. (...) W trakcie myślenia posługujemy się przeto miast samymi rzeczami - ograniczoną ilością słów, liter, symboli (...). Znaki zaś napisane, narysowane lub gdzieś wyryte nazywają się charakterami. Znaki są tym bardziej pożyteczne, im pełniej pojęcie rzeczy wyrażają (notinem rei signatae exprimunt), tak że mogłyby posłużyć nie tylko do reprezentowania, lecz także do rozumowania" ${ }^{41}$. Rzadko jednak według Leibniza człowiek zadaje sobie trud, aby zrozumieć terminy i słowa. Jeśli więc weźmiemy pod uwagę, że „umysł zawsze myśli”, to wynika stąd, że część operacji myślowych dokonywana jest nie na samych ideach, lecz na znakach, które nie zawsze pozostają w jakimkolwiek związku z idealnym systemem reprezentacji. Język naturalny czy inny stworzony przez człowieka kod, z racji ograniczeń wynikających z natury ludzkiej może tylko zbliżać się do kodu boskiego, ale ponieważ człowiek jest z istoty swej skazany na błądzenie, zatem

38 G.W. Leibniz, O rozróżnianiu zjawisk rzeczywistych od urojonych, w: tenże, Wyznanie wiary filozofa..., wyd. cyt, s. 248.

39 G.W. Leibniz, List do S. Fouchera, w: tenże, Wyznanie wiary filozofa..., wyd. cyt., s. 59.

40 „Ego ita sentio, nullam propositionem accipiendam esse nisi probatam, nec vocem nisi explicatam (...)"; G. W. Leibniz, Demonstratio propositionum primarum, AA VI, II, 479.

41 G.W. Leibniz, Podstawy formalizacji rozumowań, w: M. Gordon, Leibniz, wyd. cyt., s. 250-251. Zob. także tenże, Nowe rozważania..., wyd. cyt., t. II, s. 146. 
pod ryzyko błędu podpadają te jego działania, których celem jest naśladownictwo. Inaczej mówiąc, błąd nie jest wpisany w system natury, jest zaś skutkiem tych działań człowieka, w których usiłuje się zmierzyć z tym systemem.

Nie ma wątpliwości, że wszelka symbolika, a zwłaszcza język, jest u Leibniza integralnie sprzężona z myśleniem. Cassirer pisał, że Leibniz bardziej niż inni mu współcześni pojmował człowieka jako animal symbolicum ${ }^{42}$. Wydaje się, że mimo dzielących ich różnic, Leibniz w pewnej mierze podzielał przekonanie Hobbesa, że bez języka (mowy) nie istnieje coś, co jest atrybutem czysto ludzkim, mianowicie intelekt. Założenie, że posiadanie języka jest tym, co odróżnia człowieka od innych stworzeń, interpretowane jest przez Hobbesa w dość niezwykły sposób: język nie jest - jak dla Kartezjusza - oznaką posiadania intelektu, ale jego warunkiem. Język jest nie tylko narzędziem przekazywania myśli, ale przede wszystkim środkiem do ich powstawania. Co więcej - „prawda polega na właściwym uporządkowaniu nazw" (truth consists in the right ordering of names) ${ }^{43}$. Hobbes twierdzi więc, że gdyby człowiek nie posiadał języka, pozostawałby, podobnie jak zwierzęta, w „naturalnym” stanie całkowitej „ignorancji”, w którym nie istnieje niebezpieczeństwo błędu, gdyż nie istnieje narzędzie do formułowania sądów - „Naturalny zmysł i wyobraźnia nie są przedmiotem absurdu. Natura sama w sobie nie może się mylić" (Natural sense and imagination are not subject to absurdity. Nature itself can not err $)^{44}$. Dla Hobbesa prawda i fałsz są atrybutami mowy, a nie rzeczy, kiedy nie ma jezzyka, nie istnieje ani prawda, ani fałsz ${ }^{45}$. Leibniz zgadza się, że fałsz jest cechą myśli i zdań, prawdy należy jednak szukać w naturze rzeczy ${ }^{46}$. Pamiętać wszakże należy, że Leibniz przypisuje zwierzętom pewne funkcje umysłowe, „cień rozumowania", polegający na kojarzeniu danych zmysłowych przechowywanych w pamięci. Sama pamięć nie wystarcza jednak do poznania przyczyn pewnych doznań, zwierzęta nie posiadają bowiem ani zdolności do poznania, ani zdolności do utworzenia języka. Ów cień rozumowania nie może być ujęty pod postacią jakiegokolwiek sądu, wobec czego trudno tu mówić o prawdziwości czy fałszywości zwierzęcych zachowań. Niech nas zatem nie zwiedzie uwaga Leibniza, że ludzie w trzech czwartych swoich czynności zachowują się jak zwierzęta. To, że nie zawsze potrafimy podać przyczyn doświadczanych przez nas zjawisk, nie znaczy, iż nie jesteśmy zdolni do ich rozpoznania. Warunkiem koniecznym tej zdolności jest podniesienie tych przyczyn do poziomu świadomości i ich zrozumienie. Zrozumienie zaś polega na dostępie do wyraźnych idei rzeczy „z możnością rozmyślania

42 Zob. E. Cassirer, An Essay on Man, Yale University Press, New Haven 1962, s. 26.

43 T. Hobbes, The English Works of Thomas Hobbes, wyd. cyt., t. III, s. 23.

44 Tamże, t. III, s. 25.

45 Zob. tamże t. III, s. 23.

46 Zob. G.W. Leibniz, Dialog..., w: tenże, Wyznanie wiary filozofa..., wyd. cyt., s. 81. 
nad nimi i wysnuwania z nich prawd koniecznych. Dlatego właśnie zwierzęta nie mają wcale rozumu co najmniej w tym znaczeniu (...)" 47. Sam proces rozumienia może ulec zniekształceniu, jeśli przedmiotem świadomości stają się myśli nie pozostające w żadnym związku z ideami rzeczy. Ten stan można interpretować jako skutek ograniczeń wynikających z natury samego umysłu, ale też wydaje się, że jest on w jakimś sensie komplementarny wobec zdolności do poznania i jako taki przysługuje wyłącznie człowiekowi.

\section{Błędy pamięci}

Leibniz wyjaśnia, że: „Mamy wolną wolę nie w postrzeganiu, a w działaniu. To, że miód wydaje mi się słodki lub gorzki, nie zależy od mojej woli, ale też nie zależy od mojej woli to, że wysnuwane twierdzenie wydaje mi się prawdziwe lub fałszywe; jest przedmiotem samej tylko świadomości sprawdzenie tego, co się jej przedstawia. Ktokolwiek uznaje coś, jest świadom tego bądź na podstawie obecnego postrzeżenia czy rozumowania, albo przynajmniej na podstawie aktualnej pamięci dostarczającej minionych postrzeżeń czy postrzeżeń minionych dowodów, chociaż jesteśmy w tym często zwodzeni przez niepewną pamięć lub wadliwą uwage" 48.

Błąd jest zatem dla Leibniza funkcją tej części świadomości, która odpowiada za przechowywanie informacji, czyli pamięci. To zaś, że mamy wolną wolę w działaniu, znaczy w tym kontekście jedynie kontrolę nad uwagą i ćwiczenie pamięci. Musimy jednak wziąć pod uwage, że w istocie owa „wolność” dotyczy tych obszarów świadomości, które są z konieczności niedoskonałe i nie zawsze pozostają w związku z idealnym porządkiem wewnętrznej reprezentacji świata.

Leibniz zaprzecza, że błędy są bardziej zależne od woli niż od intelektu. Tworzymy bowiem sądy nie dlatego, że tego chcemy, ale ponieważ coś się pojawia za sprawą pamięci czy świadomości. Jest tak dlatego, że - zdaniem Leibniza - idea woli zawiera ideę rozumu i możemy chcieć tylko tego, co ujawnia się właśnie rozumowi ${ }^{49}$.

Przyczyny popełnianych przez nas błędów są takie same, jak błędów, które zdarzają się w obliczeniach arytmetycznych. Są nimi, jak pisze Leibniz, niedostatek uwagi lub pamięci. Polega to na tym, że robimy coś, czego nie powinniśmy,

47 G.W. Leibniz, Nowe rozważania..., wyd. cyt., t. II, s. 198.

48 G.W. Leibniz, Animadversiones in partem generalem Principiorum Cartesianorum, GP IV, 356.

49 Zob. G.W. Leibniz, Nowe rozważania..., wyd. cyt., t. I, s. 129, 201. 
lub myślimy, że zrobiliśmy coś, czego w istocie nie zrobiliśmy, albo zrobiliśmy nie tak jak trzeba. Podczas obliczeń (do których Leibniz porównuje wszelkie rozumowanie) zdarza się, że nie zapisujemy właściwych liczb lub opuszczamy jakieś działanie, albo nie przestrzegamy należycie samej metody. Jeśli umysł jest zmęczony lub roztargniony, nie zwraca należycie uwagi na własne działania lub przyjmuje, na skutek błędnej pamięci, że coś, co zostało w nas bardziej utrwalone tylko dlatego, że bardziej wryło się w pamięć, jest już dawno dowiedzione ${ }^{50}$.

Środki zaradcze przeciw błędom są również takie same, jak przy błędach rachunkowych. Leibniz zaleca zwracanie uwagi zarówno na rzecz, jak i na formę. Postuluje, aby postępować powoli, powtarzać i odróżniać działania, wprowadzać testy i sprawdziany, dzielić długie łańcuchy rozumowań na części, aby umysł miał czas odpocząć i potwierdzać każdą część stosownym dowodem. Podstawową umiejętnością jest, według niego, tak zwana „przytomność umysłu”, pozwalająca pokonać niesprzyjające okoliczności. Dzięki tej sprawności, która wymaga treningu, umysł będzie zdolny do prawdziwego krytycyzmu. Ten krytycyzm wyznaczony jest przez obecny stopień naszej doskonałości i nie zależy wcale od naszej woli, choć sprawą woli właśnie jest przygotowanie umysłu do właściwego działania ${ }^{51}$. W katalogu zaleceń usprawniajacych działanie umysłu zasadnicze znaczenie ma sposób przechowywania danych i metody ich analizy. Zwróćmy uwage, że rozważając problem błędu Leibniz wyraźnie odwołuje się do „porządku naszych odkryć", który jest porządkiem historycznym, nie zawsze zgodnym z idealnym porządkiem myśli. Podstawowym narzędziem archiwizacji danych jest tekst językowy. Leibniz twierdzi wręcz, że „bez pisma trudno by było budować naukę, skoro pamięć nie jest dostatecznie pewna" ${ }^{52}$. Znaczy to także, że część informacji przechowywana jest w pamięci w postaci językowej lub za pomocą pewnej symboliki, ale nie stwarza to gwarancji prawdziwości danych. Użyteczność symboliki rozpatruje Leibniz na podstawie ideogramów, o których zakłada, że „stosowane równolegle $\mathrm{z}$ pismem standardowym byłyby wielce pożyteczne dla wzbogacenia wyobraźni i dla dostarczenia mniej przytłumionych i mniej wer-

50 Zob. G.W. Leibniz, Animadversiones in partem generatem..., GP IV, 358.

51 Zob. G.W. Leibniz, Animadversiones in partem generalem..., GP IV, 361. Leibniz analizując problem błędu, zwraca uwagę, że ludzka pamięć nie funkcjonuje wcale według pewnych obiektywnych i racjonalnych zasad, które można precyzyjnie opisać, ale według pewnego nie dającego się uchwycić porządku. Nie wiadomo bowiem, dlaczego niejako na równych prawach zapamiętywane są fakty, zdarzenia czy informacje oraz wyimaginowane twory i obrazy naszej fantazji, marzenia, sny. Leibniz, zainteresowany problematyką psychologiczną analizował również marzenia senne. Zob. AA VI, II, 276-278. Wkład Leibniza w rozwój nowożytnej psychologii opisuje Daniel L. Schacter w artykule Implcit Memory, „Journal of Experimental Psychology: Learning, Memory and Cognition", vol. 13, July 1983, Nb. 3.

52 G.W. Leibniz, Nowe rozważania..., wyd. cyt., t. II, s. 146. 
balnych myśli, aniżeli te, które obecnie miewamy" 53 . Zadaniem symboliki jest więc niejako uaktywnianie samego myślenia. Gromadzone w pamięci dane maja różny status. Mogą to być dane obserwacyjne, uświadomione prawdy konieczne, przekonania, marzenia senne, hipotezy itd. Wskazując na tak zwana „przytomność umysłu", Leibniz ma na uwadze umiejętność ich rozróżniania, która objawia się jako zdolność do podania dowodu lub definicji, pozwalająca rozstrzygnąć o analogii pomiędzy naszymi myślami a wewnętrznym systemem reprezentacji. Innymi słowy, chodzi tu o ustalenie, czy myśli ujęte w słowa odzwierciedlają ów porządek zgodnie z Leibnizjańską teorią reprezentacji. Prawdziwy krytycyzm pozwala przezwyciężyć błędy pamięci, pomaga także zwalczyć wynikającą z ograniczeń słabość natury ludzkiej. Bowiem „zapał dla naszych hipotez nie jest niczym innym tylko skutkiem żywionej przez nas żądzy nakazywania dla siebie respektu" 54 .

\section{Zakończenie}

Wydaje się, że recepcję Leibniza w dużej mierze kształtuje ciągle jeszcze interpretacja B. Russella, dzieląca jego filozofię na popularną i ezoteryczną i przyznajacca wartość wyłącznie tej drugiej, opartej na dwu przesłankach logicznych prawie sprzeczności i zasadzie racji dostatecznej. Jak pisze Russell, Leibniz niezłomnie wierzył w wartość logiki nie tylko w jej własnej dziedzinie, lecz także jako fundamentu metafizyki. Należy wszakże dodać, że logika jest także fundamentem jego filozofii umysłu i filozofii języka, a podstawowe założenia tego systemu znajdujemy w tekstach tak zwanej „filozofii popularnej”. Być może to pod wpływem autorytetu Russella, twierdzacego, że „Leibniz pisał ciężko, a wpływ, jaki wywarł na filozofię niemiecką sprawił, że stała się jałowa i pedantyczna" ${ }^{55}$, Devlin, doceniając Leibnizjański rachunek różniczkowy i całkowy oraz algebrę pojęć, mimo wszystko „żegna Kartezjusza”, zaś Chomsky w kartezjanizmie znajduje filozoficzne oparcie dla swojej teorii języka, choć sam Kartezjusz kwestii językowych jeśli nie ignorował, to traktował je wyłącznie marginalnie.

53 Tamże, t. II, s. 20.

54 Tamże, t. II, s. 406.

55 Zob. B. Russell, Dzieje filozofii Zachodu, tłum T. Baszniak, A. Lipszyc, M. Szczubiałka, Aletheia, Warszawa 2000, s. 669-683. 


\section{ON SOME ASPECTS OF LEIBNIZIAN THEORY OF MIND}

\section{Summary}

While reading on the cover of the Polish edition of the book Goodbye, Descartes: the End of Logic and the Search for a New Cosmology of the mind, the words written by the well known American mathematician Keith Devlin, we discover that the reflection on language and human perception has played a major role in the history of philosophy and science. Nowadays in times of artificial intelligence research and the development of information technology, the role of psychologists, language philosophers, sociologists and linguists has gained significant weight. The answers to questions like: What is language? What is the human mind? How do we think?, are of key importance to resolving primary IT problems. The birth of a new discipline, cognitive science, which deals with the structure of the mind, thinking and consciousness became a challenge for the philosophical tradition like cartesianism, and at the same time became a pivotal factor of IT and communication techniques development. Devlin settles with tradition, which in his opinion is mainly defined by Descartes himself, however not only by his philosophy but also his methodology. Of course Descartes may be regarded as the symbol of the rationalist heritage albeit it seems that having a major impact on contemporary philosophy, it is not Descartes who should become the main character of the never ending goodbye, but Leibniz. The text is not an attempt at a polemic with Devlin's opinions, but rather a supplementation of his standpoint. The problems of Leibnizian theory of the mind which were built on the language fundaments shall be elaborated on, as they can visualize Leibniz as the real pioneer of modern cognitive science.

Key words: Leibniz, theory of mind, language

Słowa kluczowe: Leibniz, teoria umysłu, język

\section{Bibliografia}

Cassirer E., An Essay on Man, Yale University Press, New Haven 1962.

Copleston F., Historia filozofii, tłum. J. Marzęcki, Instytut Wydawniczy PAX, Warszawa 1995.

Davies P., Plan Stwórcy, tłum. Marek Krośniak, Wydawnictwo ZNAK, Kraków 1996.

Devlin K., Żegnaj Kartezjuszu. Rozstanie z logika w poszukiwaniu nowej kosmologii umystu, tłum. B. Stanosz, Prószyński i S-ka, Warszawa 1999.

Drozdek A., Leibniz: Struggles with Infinity, w: On Leibniz Legacy in the 350 Anniversary of His Birth, series: „Studies in Logic, Grammar and Rhetoric”, Białystok 1997.

The English Works of Thomas Hobbes, red. W. Moleswortha, J. Bohn, London 1839-1845, t. III.

Gordon M., Leibniz, Wiedza Powszechna, Warszawa 1973.

Leibniz G.W., Die philosophischen Schriften von G. W. Leibniz, vol. VII, pod red. C. I. Gerhardta, Halle 1849-1863 repr. Hildesheim 1960. 
Leibniz G.W., Nowe rozważania dotyczace rozumu ludzkiego, tłum. Izydora Dąmbska, PWN, Warszawa 1955.

Leibniz G.W., Philosophical Papers and Letters, pod red. L. E. Loemkera, Dordrecht: D. Reidel Publishing Company, Dordrecht 1965.

Leibniz G.W., Sämtliche Schriften und Briefe, herausgegeben von der Preussischen (ject Deutschen) Akademie der Wissenschaften zu Berlin, 6 Reihen, Darmstadt 1923, Leipzig 1983, Berlin 1950.

Leibniz G.W., Wyznanie wiary filozofa, Rozprawa metafizyczna, Monadologia, Zasady natury $i$ taski oraz inne pisma filozoficzne, tłum. S. Cichowicz, J. Domański, H. Rzeczkowski, H. Moese, opracował i wstępem poprzedził S. Cichowicz, PWN, Warszawa 1969.

Marciszewski W., Why Leibniz should not have believed in „filum cogitationis”, w: Leibniz und Europa, VI Internationaler Leibniz-Kongreß Vortrage, Hannover 1994.

Marciszewski W., Leibniz's Idea of Automated Reasoning Compared with Modern Al, w: On Leibniz Legacy in the 350 Anniversary of His Birth, series: „Studies in Logic, Grammar and Rhetoric", Białystok 1997.

Platon, Listy, tłum. M. Maykowska, PWN, Warszawa 1987.

Russell B., Dzieje filozofii Zachodu, tłum T. Baszniak, A. Lipszyc, M. Szczubiałka, Warszawa, Aletheia 2000.

Schacter D.L., Implcit Memory, „Journal of Experimental Psychology: Learning, Memory and Cognition", vol. 13, July 1983, Nb. 3.

Zauderer-Naaman N., The Challenge Posed by the Problem of Error for Leibniz's Metaphysic, w: Leibniz und Europa, VI Internationaler Leibniz-Kongreß Vortrage, I Teil, Hannover 1994.

prof. dr hab. Halina Święczkowska, Uniwersytet w Białymstoku, Zakład Semiotyki Logicznej 